\title{
Gambling and hospital lotteries: looking out for losers
}

\author{
John Fletcher MB BChir MPH
}

I have just finished reading Charles Dickens' The Old Curiosity Shop, which has as its subject the devastating effect of an old man's gambling on the people he loves. Dickens depicts well the flawed reasoning that grips an otherwise intelligent mind; the betrayal to which the old man will stoop to feed his craving to win back what he has lost; and, above all, his vulnerability and that of his granddaughter, Nell, to further misfortune.

It is tempting to believe that times have changed and that problem gambling is now uncommon, affecting only a small proportion of the people who participate. However, a news article in the July issue of CMAJ paints a different picture. ${ }^{1}$ Across Canada, about $4 \%$ of the population may be classified as problem gamblers. The proportion of gambling revenue these players generate is $23 \%$.

Gambling may not have the direct biological effects of other addictive behaviours, but it is potentially unlimited in its capacity to drain addicts' finances in a short time, rendering them and their dependents paupers. Consuming more than a few hundred dollars' worth of alcohol or cigarettes in a weekend is difficult, whereas spending thousands of dollars on gambling in the same amount of time is quite easy. Few governments have introduced effective measures to limit the harm caused by gambling, in contrast to measures aimed at curbing tobacco and alcohol consumption.

Because lotteries were illegal in Canada until 1969, lotteries to fund health care are fairly recent phenomena. Toronto's Hospital for Sick Children held its first lottery in 1996. Lotteries have been substantial funders of research, teaching and health care - larger hospitals now raise \$10 million or more from lotteries annually, and smaller hospitals generate close to $\$ 1$ million. A typical lottery website looks exciting and features prizes such as houses, cars, holidays and cash, with enticing suggestions to buy more tickets to increase the chance of winning. For example, a single ticket may cost $\$ 100$, but the price per ticket may be halved by buying 10 ; for "only" $\$ 900$, one might purchase 30 tickets. These sums of money are not small. However, to sanction the use of lotteries for fundraising, hospitals would need to believe that such schemes cause little harm.

It is contradictory for legislation to ban hospitals from selling one potentially harmful, but legal, addictive product on their premises - tobacco - while allowing them to actively promote another - lotteries. Gambling can be addictive and has the potential to harm vulnerable people. For this reason, gambling is an area in which health professionals and hospi-

tals should take a lead. Have we lost our moral compass to such an extent that we are blinded to our duty to "first do no harm" by the attraction of easy revenue?

Little Nell's story and the weakness of her grandfather may inspire us to look to their 21st century counterparts, but are hospital lotteries really addictive and potentially ruinous to some players and their families? Truthfully, we do not know. However, should we not be sure if we are to bet the welfare of our patients and their loved ones on the assumption that lotteries are harmless? Hospitals should be leading the way to develop responsible lotteries that protect the vulnerable and minimize the potential harms associated with gambling; they should be at the forefront of research to identify and mitigate harm.

Measures that could protect vulnerable players might start with requiring personal identification. Players could be asked to specify their personal spending limits in advance, knowing that further sales would be prevented - an option available in the United Kingdom's national lottery. ${ }^{2}$ Limiting the amount that can be spent and banning bulk discounts are other measures likely to reduce players' losses, ${ }^{3}$ although such measures might also reduce a lottery's profits. However, lowering the lottery's take might be considered the price of doing the right thing; maximizing profits should not justify poor ethical practice. Alternatively, given the public's apparent appetite for ethical financial fund management and the success of such funds, hospitals might even increase their revenues by caring for their lottery customers.

For many people, purchasing a lottery ticket is a bit of fun made all the better when it is for a good cause. For others, it is a ticket on a journey of misery, marital breakdown and mental illness. As good corporate citizens, hospitals should show Canada what it means to run ethical lotteries.

\section{References}

1. Collier R. Canada needs more-aggressive problem-gambling policies, say researchers. CMAJ 2013;185:E435-6.

2. Responsible play. Watford (UK): The National Lottery. Available: www.national-lottery .co.uk/player/p/help/responsibleplay.ftl (accessed 2013 July 25).

3. Williams RJ, West BL, Simpson RI. Prevention of problem gambling: a comprehensive review of the evidence and identified best practices. Lethbridge (AB): University of Lethbridge; 2012. Available: www.uleth.ca/dspace/handle/10133/3121 (accessed 2013 July 25).

Competing interests: See www.cmaj.ca/site/misc/cmaj_staff.xhtml

Affiliations: See www.cmaj.ca/site/misc/cmaj_staff.xhtml

Correspondence to: CMAJ editor, pubs@cmaj.ca

CMAJ 2013. DOI:10.1503/cmaj.131102 